\title{
Introduction: Thematic issue of Mineralium Deposita on Orogenic Gold Deposits
}

\author{
David Groves $^{1}$ - Julian Vearncombe ${ }^{2}$
}

Published online: 3 January 2020

(C) Springer-Verlag GmbH Germany, part of Springer Nature 2020

The concept of a Thematic Issue of Mineralium Deposita on Orogenic Gold Deposits arose from a two-day Workshop entitled "Orogenic Gold from Philosophy to Exploration" organized by Geosymposia in Perth February 12-13, 2019. Many speakers at that meeting were unable to contribute to this volume with their work published elsewhere or their inability to conform to journal timing constraints. Guest Editor David Groves invited contributions from China University of Geosciences Beijing and Institute of Geology and Geophysics Chinese Academy of Sciences Beijing, because research on a number of Chinese gold provinces, particularly the giant Jiaodong gold province, is providing important differences with orogenic gold deposits elsewhere globally.

The contents are organized in a logical order from papers with direct relevance to gold exploration to those broadly related to genetic models for orogenic gold deposits.

In terms of gold exploration, and with particular reference to Western Australia, Vearncombe and Phillips argue that brownfield exploration has been more successful than previously acknowledged. Importantly, many mines that started life as Tier 2 or Tier $3(<1 \mathrm{Moz})$ have through organic growth become Tier 1 ( $>6 \mathrm{Moz})$. There is no crisis related to underperformance of greenfield exploration as brownfield success has maintained gold production in Australia. Importantly, greenfield exploration does not need to locate Tier 1 deposits, as this can and does happen after mining has commenced.

Hronsky emphasizes the importance of fluid focusing and presents an interpretation of deposit-scale controls on orogenic gold deposits, with particular emphasis on the Telfer deposit

\section{David Groves}

di_groves@hotmail.com

1 Orebusters Pty Ltd., Gwelup, Western Australia 6018, Australia

2 SJS Resource Management, Mount Pleasant, Western Australia 6153, Australia
(Western Australia) and its component ore shoots, introducing several novel concepts in the discussion. He proposes that the rheological architecture of the host rock mass is an important predictive input for exploration targeting.

Cowan then introduces a deposit-scale structural analysis method using readily available drill sample data that lack structural measurements. He details studies at the influential SigmaLamaque deposit (Quebec), highlighting the 3D structural architecture from grade, lithology and stope wireframes, but avoiding the assumptions of published structural models. This first-principles approach applies basic field techniques directly to drilling data using a modern $3 \mathrm{D}$ viewer and interprets the controls on gold at multiple scales, a task that could not be readily achieved at the deposit scale in the twentieth century.

Finally, in this section, Jia et al. present an analysis of the use of immobile elements to define critical host rocks for orogenic gold deposits, with particular emphasis on the deposits in the Sandstone greenstone belt of Western Australia.

In terms of metallogenic models at the global scale, Groves et al. summarize evidence for a sub-crustal ore-fluid source and propose that the genesis of orogenic gold deposits is either directly or indirectly related to subduction in convergentmargin geodynamic settings. There follows a series of papers on new research and genetic models for Chinese orogenic gold provinces at district to deposit scale.

Models for the sub-crustal generation of ore components for deposits in the giant Jiaodong Gold Province, on the margin of the North China Block, are presented by Deng et al. who, for the Jiaodong province, record a substantial time gap between Precambrian regional metamorphism and gold mineralization in the Mesozoic. They argue for remobilization of earlier metasomatized, anomalously gold-rich mantle lithosphere as the source of ore fluid, sulfur and metals.

Feng et al. use zircon and monazite ages combined with stable isotope data to determine that gold mineralization at the Daliahang deposit (Jiaodong Gold Province, eastern China) occurred significantly after the igneous events, and they also argue for a deep-sourced mineralizing fluid. 
The complex geodynamic evolution of the Aliaoshan gold province, along the margin of the Yangtze Block southeastern Tibet, is discussed by Wang et al. (a) who present regional geotectonic and sulfur isotope arguments for a derivation of gold from metasomatized mantle lithosphere. In a second paper by the same senior author, Wang et al. (b), the source of the amphibolite-facies Danba deposit gold is discussed. A subcrustal ore fluid from metasomatized and fertilized mantle lithosphere is the preferred source of both metals and sulfur.

Qiu et al. continue the Chinese theme using monazite dating to assess the genesis of the Zaozigou Au-Sb deposit in the West Qinling Orogen. They conclude that mineralization was about 30 my after magmatism, and interpret the $\mathrm{Au}-\mathrm{Sb}$ mineralization to be of metamorphic-hydrothermal derivation in the West Qinling Orogen, between the North China and Yangtze Blocks.

Zhang et al. then follow with documentation of overprinting of barren quartz veins by relatively quartz-poor sulfide-gold mineralization at Huangjindong in the Jiangnan Orogen (southeastern China). This sounds a warning about sampling gold-rich veins for fluid inclusion or isotope analyses without careful documentation of vein paragenesis.

Finally, in this section, Witt et al. present a discussion of the complex evolution of the anomalous $\mathrm{Co}-\mathrm{Au}$ deposits in the Kusamo Schist Belt of Finland in terms of a potential orogenic gold association.

The Guest Editors have every confidence that this Thematic Issue will be a landmark publication, both in terms of development of holistic models for orogenic gold deposits and their exploration significance and in terms of depositscale controls on ore shoots that aid brownfield exploration, the current mainstay of the gold mining industry.

David Groves would like to acknowledge support that assisted his access to digital library services and Chinese interaction from Professor Jun Deng and his research team and from 111 Project of the Ministry of Science and Technology (BP0719021), the National Natural Science Foundation of China (41230311, 41572069). 